\title{
Influence of Temperature on the Fracture Parameters of Basalt Fiber Concrete
}

\author{
N. Shiva kumar ${ }^{1}$ and Dr. T. Muralidhara Rao ${ }^{2}$ \\ ${ }^{1}$ PG Scholar, CVR College of Engineering/Civil Engg. Department, Hyderabad, India \\ Email: nshivakumarneela@gmail.com \\ ${ }^{2}$ Professor, CVR College of Engineering/Civil Engg. Department, Hyderabad, India \\ Email: tmuralidhararao@gmail.com
}

\begin{abstract}
In the present study, the effect of elevated temperatures on the strength parameters and fracture parameters of plain and basalt fiber high strength concrete was studied at the end of $\mathbf{2 8}$ days of conventional curing. The study was done for $100^{\circ} \mathrm{C}, \quad 300^{\circ} \mathrm{C}, \quad 500^{\circ} \mathrm{C}, \quad 700^{\circ} \mathrm{C}$ and $900^{\circ} \mathrm{C}$ temperatures for 02 hours in a high temperature furnace of $1000^{\circ} \mathrm{C}$ capacity. The percentage decrease in strength parameters and fracture parameters was increased for plain and basalt fiber concrete specimens with the increase in the temperature.
\end{abstract}

Index Terms: Elevated temperatures, compressive strength, modulus of elasticity, fracture energy, fracture toughness, basalt fiber

\section{INTRODUCTION}

Basalt is a type of igneous rock formed by the rapid cooling of lava at the surface of earth. Crushed basalt rock is the only raw material required for manufacturing the fiber. Characteristics of Basalt rock vary from the source of lava, cooling rate, and historical exposure to the elements. Though basalt rocks are available in different compositions, only certain compositions and characteristics can be used for making the continuous filaments with a diameter range of 9 to 24 microns. Basalt rocks with $\mathrm{SiO} 2$ content about $46 \%$ (acid basalt) are suitable for fiber production. Basalt fiber is composed of minerals plagioclase, pyroxene, and olivine. Basalt fibers are available in different lengths of 3,6,9,12,18 and 24mm having diameters 13-20 microns.

\section{LITERATURE REVIEW}

Aathithya Raja M, Saravanan G, Satheesh.V. S [3] used basalt chopped fibre of length $6 \mathrm{~mm}$ and $12 \mathrm{~mm}$ to study the compressive strength, flexural strength and split tensile strength. The addition of basalt chopped fibres to concrete improved the tensile strength and flexural strength significantly compared to plain concrete due to the ability to hold on crack surfaces of concrete.

N. Gopi, P. Baskar, B. Dharani and P. Abinaya[4] investigated the Mechanical properties of fiber reinforced concrete cubes, cylinders and prisms (M20 Grade) by varying the percentage of fibers $(0.20 \%, 0.25 \%$, and $0.30 \%)$. It was found that the addition of basalt fibre in concrete changes the mode of failure from brittle to ductile failure when subjected to compression, bending and impact. The experimental results showed that the compressive strength of Basalt fibre concrete was $38.34 \mathrm{~N} / \mathrm{mm}^{2}$ which is $22 \%$ higher than control concrete of $31.34 \mathrm{~N} / \mathrm{mm}^{2}$. The Basalt fibre concrete exhibited higher tensile strength than the normal concrete. The tensile strength of basalt fibre concrete was $7.66 \mathrm{~N} / \mathrm{mm}^{2}$ which is $45 \%$ higher than the tensile strength of normal concrete $\left(5.26 \mathrm{~N} / \mathrm{mm}^{2}\right)$.

Mohammed Ishtiyaque and M.G. Ghaikh[5] studied the effect of addition of basalt fibers at $0.25 \%, 0.5 \%, 0.75 \%, 1 \%$ (of volume of concrete) on fracture properties of concrete was studied. The test results showed an improvement in tensile strength and fracture properties of basalt fiber reinforced concrete mixes when compared with the normal mix. Tensile strength increased by $11 \%$ with addition of $0.25 \%$ basalt fibers. Fracture toughness also increased by $402 \%$ and $269 \%$ with addition of $0.25 \%$ and $0.75 \%$ of basalt fibers. But workability and compressive strengths reduced with the increased basalt fiber percentage.

M.P.Sureshkumar, S.Ramesh, P.Easwaran, P.Pruthviraj [7] discussed about the properties, advantages and application of basalt fiber in various concrete works. Basalt fiber has high oxidation resistance, high softening and melting temperatures, higher young's modulus and tensile strength properties than that of glass fiber and it has better fire resisting property compared to the glass fiber. The basalt fiber rebar having full resistance against corrosion may be good alternative for the reinforcement of concrete structures, like RC bridge girders subjected to an environmental attack. Finally, it was concluded that the basalt fiber can be used as a good alternative strengthening material instead of glass fiber, carbon fiber, steel fiber, etc.

Suchita Hirde and Sagar Shelar[8] studied the variation of compressive strength, flexural strength and split tensile strength of M40 grade concrete with various percentages ( $0 \%$ to $5 \%$ by weight of cement at interval of $1 \%$ ) of basalt fiber. The length of fiber used was $18 \mathrm{~mm}$ length. The compressive strength increased by $7.31 \%$ for $3 \%$ basalt fiber content. Flexural strength increased by $57.14 \%$ for 5 $\%$ basalt fiber. Split tensile strength increased by $33.6 \%$ for $4 \%$ basalt fiber content. 


\section{EXPERIMENTAL STUDY}

\section{A. Cement}

Ordinary Portland Cement of 53 grade conforming to IS:8112-1989 was used in the present study.

\section{B. Aggregates}

The physical properties of Fine aggregate and coarse aggregate used in the present study are presented in Table I.

TABLE I.

Physical Properties of Aggregates

\begin{tabular}{|c|c|c|}
\hline Physical property & $\begin{array}{c}\text { Fine } \\
\text { aggregates }\end{array}$ & $\begin{array}{c}\text { Coarse } \\
\text { aggregates }\end{array}$ \\
\hline Specific Gravity & 2.65 & 2.70 \\
\hline Fineness Modulus & 2.87 & 7.10 \\
\hline Water Absorption & $1.5 \%$ & $0.8 \%$ \\
\hline
\end{tabular}

Fine aggregate in the concrete mix was taken in the following proportions. $2.36 \mathrm{~mm}=10 \% ; 1.18 \mathrm{~mm}=30 \% ; 600$ microns $=25 \% ; 300$ microns $=25 \% ; 150$ microns $=10 \%$. Coarse aggregate in the concrete mix was taken in the following proportions. $20 \mathrm{~mm}$ passing and $10 \mathrm{~mm}$ retained= $60 \% ; 10 \mathrm{~mm}$ passing and $4.75 \mathrm{~mm}$ retained $=40 \%$.

\section{Water}

Potable water was used in the preparation of concrete. Water used conforms to IS:456-2000.

\section{Mineral Admixture}

Ultrafine material 'Alccofine1203' conforming to IS:12089-1987 and IS:456-2000 (Clause No:5.2.2) was used as a supplementary cementitious material. Its particle size is much finer than the cement particle size. Ten percent of cement is replaced by alccofine 1203 . 10\% replacement of cement is found to be the optimum percentage of replacement to produce the desired high strength concrete. The physical properties and chemical properties of Alccofine 1203 are given in Table II and Table III respectively.

TABLE II.

Physical Properties of Alccofine 1203

\begin{tabular}{|l|l|l|l|l|l|}
\hline $\begin{array}{l}\text { Specifi } \\
\text { gravity }\end{array}$ & $\begin{array}{l}\text { Bulk density } \\
\left(\mathrm{kg} / \mathrm{m}^{3}\right)\end{array}$ & $\begin{array}{l}\text { Fineness } \\
\left(\mathrm{cm}^{2} / \mathrm{gm}\right)\end{array}$ & \multicolumn{3}{|l|}{$\begin{array}{l}\text { Particle size distribution } \\
(\mu)\end{array}$} \\
\hline 2.9 & 680 & 12000 & $\mathrm{D} 10$ & $\mathrm{D} 50$ & $\mathrm{D} 90$ \\
\cline { 4 - 6 } & & & $1-2$ & $4-5$ & $8-9$ \\
\hline
\end{tabular}

TABLE III.

Chemical Properties of Alccofine 1203

\begin{tabular}{|l|l|l|l|l|l|l|}
\hline $\mathrm{CaO}$ & $\mathrm{Al}_{2} \mathrm{O}_{3}$ & $\mathrm{SiO}_{2}$ & $\mathrm{Fe}_{2} \mathrm{O}_{3}$ & $\mathrm{SO}_{3}$ & $\mathrm{MgO}$ & Glass \\
\hline $34 \%$ & $24 \%$ & $35 \%$ & $1.2 \%$ & $0.13 \%$ & $8.2 \%$ & $>90 \%$ \\
\hline
\end{tabular}

\section{E. Chemical Admixture}

Superplasticizer used in the present study was MasterEASE3709(BASF Product). It is based on the modified polycarboxylic ether used for workability of concrete at fresh state. $1.5 \%$ by weight of binder was used in the concrete mix for workability.

\section{F. Basalt fiber}

In the present study $18 \mathrm{~mm}$ length basalt fibers were used. The chemical composition of basalt fiber is shown in the below Table IV.

TABLE IV.

CHEMICAL COMPOSITION OF BASALT FiBER

\begin{tabular}{|c|c|c|}
\hline S.No & Chemical Name & Percentage \\
\hline 1 & $\mathrm{Sio}_{2}$ & $51.6 \%-59.3 \%$ \\
\hline 2 & $\mathrm{Al}_{2} \mathrm{O}_{3}$ & $14.6 \%-18.3 \%$ \\
\hline 3 & $\mathrm{Cao}$ & $5.9 \%-9.44 \%$ \\
\hline 4 & $\mathrm{Mgo}$ & $3.0 \%-5.33 \%$ \\
\hline 5 & $\mathrm{Na}_{2} \mathrm{O}_{\mathrm{k}} \mathrm{O}$ & $3.6 \%-5.2 \%$ \\
\hline 6 & $\mathrm{TiO}_{2}$ & $0.8 \%-2.25 \%$ \\
\hline 7 & $\mathrm{Fe}_{2} \mathrm{O}_{3}+\mathrm{Feo}$ & $9.0 \%-14 \%$ \\
\hline 8 & Others & $0.09 \%-0.13 \%$ \\
\hline
\end{tabular}

Physical Properties of Basalt fibers:

Sustained operating temperature -

Minimum operating temperature $-(-) 260^{\circ} \mathrm{C}$

Melting Temperature

$\begin{array}{ll}-\quad & 1450^{\circ} \mathrm{C} \\ - & 2.6 \mathrm{~g} / \mathrm{cm}^{3}\end{array}$

Density

Elastic Modulus

Elongation at break

Tensile Strength

Filament Diameter

$-\quad 2.6 \mathrm{~g} / \mathrm{cm}$
$-\quad 93 \mathrm{Gpa}$

- $\quad 3.15 \%$

- 3200-3850Mpa

- $\quad$ 13-20 microns

\section{G. Mix Proportion}

Mix proportion used was 1:0.556:1.629:0.25. Using Absolute Volume Method, materials required are calculated as Cement $=721.643 \mathrm{~kg} / \mathrm{m}^{3}$; Fine Aggregate $=401.233$ $\mathrm{kg} / \mathrm{m}^{3}$; Coarse Aggregate $=1175.556 \mathrm{~kg} / \mathrm{m}^{3}$; Water $=$ $180.410 \mathrm{~kg} / \mathrm{m}^{3}$.

\section{Test Results}

\section{A. Compressive strength}

Eighteen, 100mm plain concrete cubes and eighteen $100 \mathrm{~mm}$ basalt fiber concrete cubes were cast and tested for studying the effect of elevated temperatures on the compressive strength. Each cube was tested for residual compressive strength under $3000 \mathrm{kN}$ Compression Testing Machine.

At the end of 28 days of conventional curing, cubes cast were taken out and air dried and tested for $100^{\circ} \mathrm{C}, 300^{\circ} \mathrm{C}$, $500^{\circ} \mathrm{c}, 700^{\circ} \mathrm{C}$ and $900^{\circ} \mathrm{C}$ temperatures for 02 hours in a high temperature furnace of $1000^{\circ} \mathrm{C}$ capacity. After 02 hours, cubes were taken out of the furnace and allowed to cool. 
TABLE V.

Compressive Strength of Plain and Basalt Fiber CONCRETE Cubes

\begin{tabular}{|c|c|c|}
\hline \multicolumn{3}{|c|}{ Plain concrete cubes } \\
\hline $\begin{array}{c}\text { Temperature } \\
\left({ }^{0} \mathrm{C}\right)\end{array}$ & $\begin{array}{l}\text { Avg residual compressive } \\
\text { strength }(\mathrm{Mpa})\end{array}$ & $\begin{array}{l}\text { Percentage decrease } \\
\text { in avg. residual } \\
\text { strength }\end{array}$ \\
\hline 20 & 79.2 & -- \\
\hline 100 & $75 . .5$ & 4.7 \\
\hline 300 & 72.5 & 8.5 \\
\hline 500 & 71.5 & 9.7 \\
\hline 700 & 42 & 46.9 \\
\hline 900 & 14.5 & 81.7 \\
\hline \multicolumn{3}{|c|}{ Basalt fiber concrete cubes } \\
\hline $\begin{array}{c}\text { Temperature } \\
\left({ }^{0} \mathrm{C}\right)\end{array}$ & $\begin{array}{l}\text { Avg residual compressive } \\
\text { strength }(\mathrm{Mpa})\end{array}$ & $\begin{array}{l}\text { Percentage decrease } \\
\text { in avg. residual } \\
\text { strength }\end{array}$ \\
\hline 20 & 81.5 & --- \\
\hline 100 & 80 & 1.84 \\
\hline 300 & 77.5 & 4.9 \\
\hline 500 & 77 & 5.5 \\
\hline 700 & 58 & 28.8 \\
\hline 900 & 33 & 59.5 \\
\hline
\end{tabular}

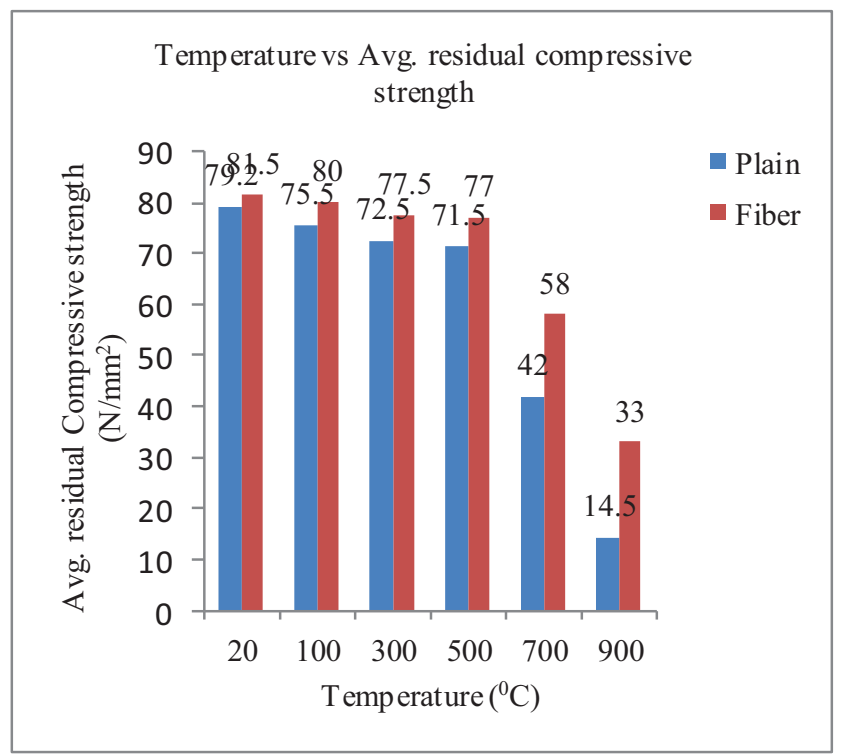

Figure 1. Average residual Compressive strength of Plain and Basalt fiber concrete cubes at different temperatures

room temperature before testing for their compressive strength.

The average residual compressive strength and percentage decrease in average residual compressive strength of $100 \mathrm{~mm}$ plain and basalt fiber concrete cubes are presented in Table $\mathrm{V}$ and Fig. 1.

\section{B. Flexural strength}

Eighteen, $100 \mathrm{mmX} 100 \mathrm{mmX} 420 \mathrm{~mm}$ plain concrete prisms and eighteen $100 \mathrm{mmX} 100 \times 420 \mathrm{~mm}$ basalt fiber concrete prisms were cast and tested for studying the effect of elevated temperatures on the Flexural strength. Each prism
TABLE VI.

Flexural Strength of Plain and Basalt Fiber CONCRETE PRISMS

\begin{tabular}{|c|c|c|}
\hline \multicolumn{3}{|c|}{ Plain concrete prisms } \\
\hline $\begin{array}{c}\text { Temperature } \\
\left({ }^{0} \mathrm{C}\right)\end{array}$ & $\begin{array}{c}\text { Avg residual flexural } \\
\text { strength (Mpa) }\end{array}$ & $\begin{array}{c}\text { Percentage decrease } \\
\text { in avg. residual } \\
\text { flexure }\end{array}$ \\
\hline 20 & 18.45 & -- \\
\hline 100 & 16.91 & 8.4 \\
\hline 300 & 16.38 & 11.2 \\
\hline 500 & 13.81 & 25.2 \\
\hline 700 & 7.5 & 59.35 \\
\hline 900 & 5.4 & 70.7 \\
\hline \multicolumn{3}{|c|}{ Basalt fiber concrete prisms } \\
\hline Temperature & $\begin{array}{c}\text { Avg residual flexural } \\
\text { strength (Mpa) }\end{array}$ & $\begin{array}{c}\text { Percentage decrease } \\
\text { in avg. residual } \\
\text { flexure }\end{array}$ \\
\hline 20 & 22.35 & -- \\
\hline 100 & 21.25 & 4.9 \\
\hline 300 & 20.5 & 14.36 \\
\hline 500 & 19.14 & 37.5 \\
\hline 700 & 13.98 & 42.9 \\
\hline 900 & 12.75 & \\
\hline
\end{tabular}

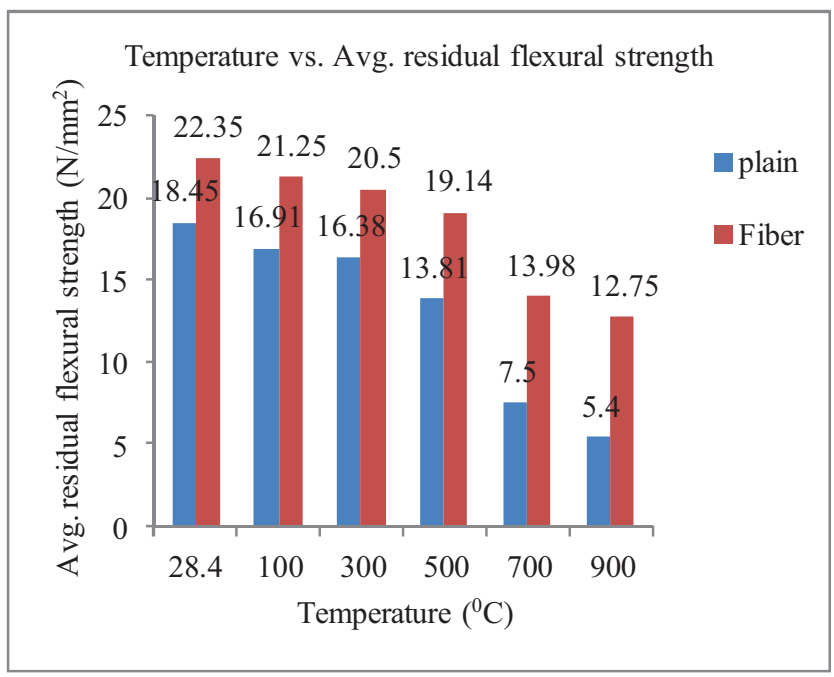

Figure 2. Residual Flexural strength of plain concrete prisms and fiber concrete prisms at different temperatures

was tested for residual flexural strength under Universal Testing Machine.

At the end of 28 days of conventional curing, prisms were taken out from water and air dried and tested for $100^{\circ} \mathrm{C}$, $300^{\circ} \mathrm{C}, 500^{\circ} \mathrm{c}, 700^{\circ} \mathrm{C}$ and $900^{\circ} \mathrm{C}$ temperatures for 02 hours in a high temperature furnace of $1000^{\circ} \mathrm{C}$ capacity. After 02 hours, prisms were taken out of the furnace and allowed to cool at room temperature before testing for their flexural strength.

The average residual flexural strength and percentage decrease in average residual flexural strength of $100 \mathrm{mmX} 100 \mathrm{mmX} 420 \mathrm{~mm}$ plain and basalt fiber concrete prisms are presented in Table VI and Fig. 2.

Between $100^{\circ} \mathrm{C}$ to $900^{\circ} \mathrm{C}$, the percentage decrease in residual flexural strength was increased for both plain concrete prisms and basalt fiber concrete prisms.

\section{Split tensile strength}

Eighteen,300mm length and $150 \mathrm{~mm}$ diameter plain concrete cylinders and eighteen $300 \mathrm{~mm}$ length and $150 \mathrm{~mm}$ diameter basalt fiber concrete cylinders were cast and tested 
for studying the effect of elevated temperatures on the split tensile strength. Each cylinder was tested for residual split tensile strength under compression Testing Machine.

At the end of 28 days of conventional curing, cylinders cast were taken out and air dried and tested for $100^{\circ} \mathrm{C}$, $300^{\circ} \mathrm{C}, 500^{\circ} \mathrm{c}, 700^{\circ} \mathrm{C}$ and $900^{\circ} \mathrm{C}$ temperatures for 02 hours in a high temperature furnace of $1000^{\circ} \mathrm{C}$ capacity. After 02 hours, cylinders were taken out of the furnace and allowed to cool at room temperature before testing for their split tensile strength. The average residual split tensile strength and percentage decrease in average residual split strength of $300 \mathrm{~mm}$ length and $150 \mathrm{~mm}$ diameter plain and basalt fiber concrete cylinders are presented in Table VII and Fig. 3.

Between $100^{\circ} \mathrm{C}$ to $900^{\circ} \mathrm{C}$, the percentage decrease in residual split tensile strength was increased for both plain concrete cylinders and basalt fiber concrete cylinders.

TABLE VII.

SPLIT TENSILE STRENGTH OF PLAIN AND BASALT FIBER CONCRETE CYLINDERS

\begin{tabular}{|c|c|c|}
\hline \multicolumn{3}{|c|}{ Plain concrete cylinders } \\
\hline $\begin{array}{c}\text { Temperature } \\
\left({ }^{0} \mathrm{C}\right)\end{array}$ & $\begin{array}{c}\text { Avg residual split } \\
\text { tensile strength (Mpa) }\end{array}$ & $\begin{array}{c}\text { Percentage decrease } \\
\text { in avg. residual split } \\
\text { tensile strength }\end{array}$ \\
\hline 20 & 5.16 & -- \\
\hline 100 & 4.95 & 4 \\
\hline 300 & 4.13 & 19.9 \\
\hline 500 & 3.25 & 37 \\
\hline 700 & 2.26 & 64.7 \\
\hline 900 & 1.82 & $\begin{array}{c}\text { Percentage decrease } \\
\text { in avg. residual split } \\
\text { tensile strength }\end{array}$ \\
\hline \multicolumn{3}{|c|}{ Basalt fiber concrete cylinders } \\
\hline Temperature & $\begin{array}{c}\text { Avg residual split } \\
\left({ }^{0} \mathrm{C}\right)\end{array}$ & tensile strength (Mpa) \\
\hline 20 & 6.1 & 2.62 \\
\hline 100 & 5.94 & 8.52 \\
\hline 300 & 5.58 & 20.81 \\
\hline 500 & 5.21 & 45.08 \\
\hline 700 & 4.83 & \\
\hline 900 & 3.35 & \\
\hline
\end{tabular}

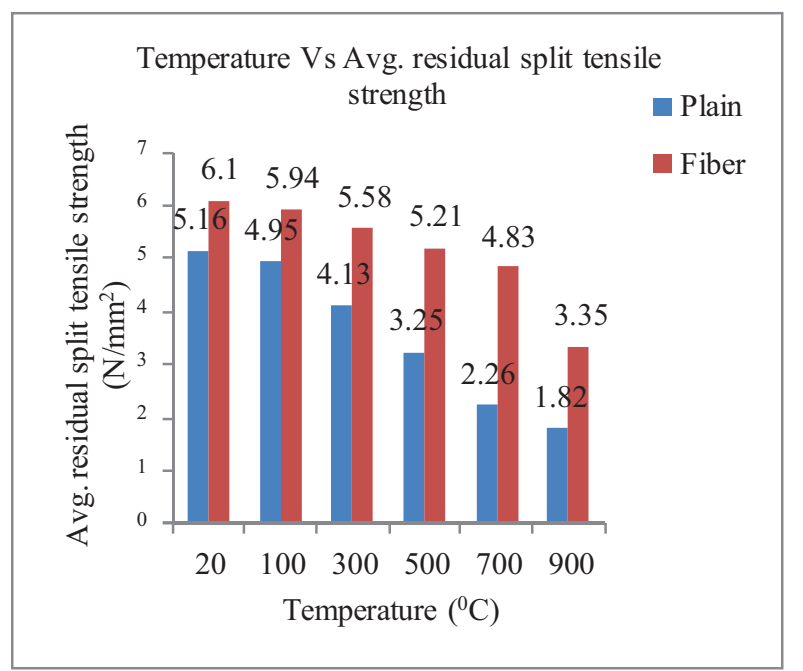

Figure 3. Average residual split tensile strengths of plain concrete cylinders and fiber concrete cylinders at different temperatures.

\section{Modulus of Elasticity}

Eighteen,300mm length and $150 \mathrm{~mm}$ diameter plain concrete cylinderss and eighteen $300 \mathrm{~mm}$ length and $150 \mathrm{~mm}$ diameter basalt fiber concrete cylinders were cast and tested or studying the effect of elevated temperatures on the Modulus of Elasticity. Each cylinder was tested for residual Modulus of Elasticiry under compression Testing Machine.

At the end of 28 days of conventional curing, cylinders cast were taken out and air dried and tested for $100^{\circ} \mathrm{C}$, $300^{\circ} \mathrm{C}, 500^{\circ} \mathrm{c}, 700^{\circ} \mathrm{C}$ and $900^{\circ} \mathrm{C}$ temperatures for 02 hours in a high temperature furnace of $1000^{\circ} \mathrm{C}$ capacity. After 02 hours, cylinders were taken out of the furnace and allowed to cool at room temperature before testing for their Modulus of Elasticity.

The average Modulus of Elasticity and percentage decrease in average Modulus of Elasticity of $300 \mathrm{~mm}$ length and $150 \mathrm{~mm}$ diameter plain and basalt fiber concrete cylinders are presented in Table VIII and Fig. 4.

TABLE VIII.

Modulus of Elasticity of Plain and Basalt FiBER CONCRETE CYLINDERS

\begin{tabular}{|c|c|c|}
\hline \multicolumn{3}{|c|}{ Plain concrete cylinders } \\
\hline $\begin{array}{c}\text { Temperature } \\
\left({ }^{0} \mathrm{C}\right)\end{array}$ & $\begin{array}{c}\text { Modulus of } \\
\text { Elasticity (Mpa) }\end{array}$ & $\begin{array}{c}\text { Percentage decrease in } \\
\text { Modulus of Elasticity }\end{array}$ \\
\hline 20 & 41668 & -- \\
\hline 100 & 39130 & 6.1 \\
\hline 300 & 35986 & 13.6 \\
\hline 500 & 31425 & 24.6 \\
\hline 700 & 23568 & 43.3 \\
\hline 900 & 15580 & 62.61 \\
\hline & Basalt fiber concrete cylinders \\
\hline Temperature & Modulus of Elasticity & $\begin{array}{c}\text { Percentage decrease } \\
\text { in Modulus of } \\
\text { (Mpa) }\end{array}$ \\
\hline$\left.{ }^{0} \mathrm{C}\right)$ & 43500 & -- \\
\hline 20 & 41392 & 10.3 \\
\hline 100 & 39000 & 13.3 \\
\hline 300 & 37700 & 41.6 \\
\hline 500 & 32040 & 26.3 \\
\hline 700 & 25415 & \\
\hline 900 &
\end{tabular}

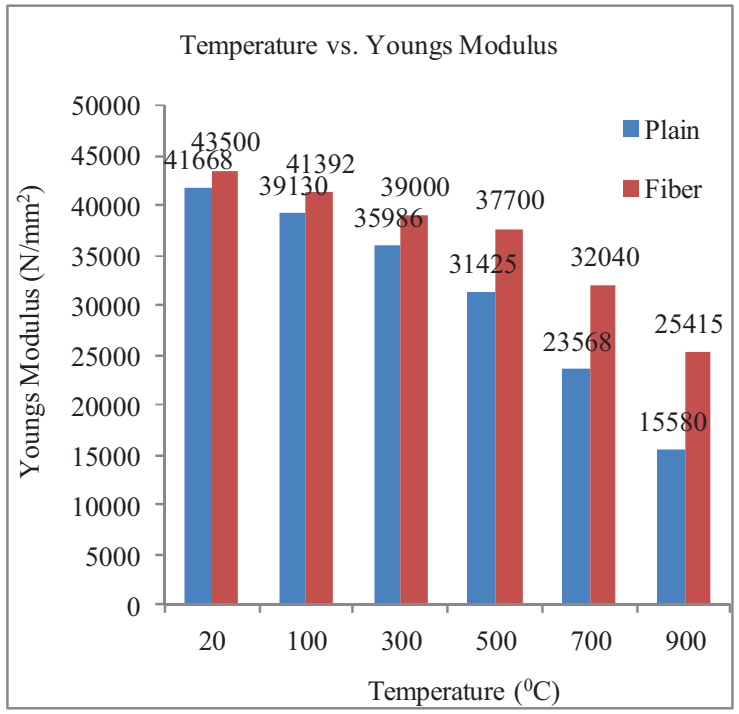

Figure 4. Average Youngs Modulus of plain concrete cylinders and fiber concrete cylinders at different temperatures. 


\section{E. Fracture Energy and Fracture Toughness}

Eighteen, $100 \mathrm{mmX} 100 \mathrm{mmX} 420 \mathrm{~mm}$ plain concrete prisms and eighteen $100 \mathrm{mmX} 100 \mathrm{X} 420 \mathrm{~mm}$ basalt fiber concrete prisms were cast and tested under Universal Testing Machine for studying the effect of elevated temperatures on the Fracture energy and Fracture toughness.

At the end of 28 days of conventional curing, prisms cast were taken out and air dried and tested for $100^{\circ} \mathrm{C}, 300^{\circ} \mathrm{C}$, $500^{\circ} \mathrm{c}, 700^{\circ} \mathrm{C}$ and $900^{\circ} \mathrm{C}$ temperatures for 02 hours in a high temperature furnace of $1000^{\circ} \mathrm{C}$ capacity. After 02 hours, prisms were taken out of the furnace and allowed to cool at room temperature before testing for their Fracture energy and Fracture toughness.

The average Fracture energy, Fracture toughness and percentage decrease in average fracture energy and Fracture toughness of $100 \mathrm{mmX} 100 \mathrm{mmX} 420 \mathrm{~mm}$ plain and basalt fiber concrete prisms are presented in Table IX, Table X, Fig.5 and Fig.6. Load-Deflection of Plain concrete prisms and basalt fiber concrete prisms at different temperatures is shown in fig. 7 and fig. 8 respectively.

TABLE IX.

FRACTURE ENERGY OF PLAIN AND BASALt FibER

CONCRETE PRISMS

\begin{tabular}{|c|c|c|}
\hline \multicolumn{3}{|c|}{ Plain concrete prisms } \\
\hline $\begin{array}{l}\text { Temperature } \\
\left({ }^{0} \mathrm{C}\right)\end{array}$ & $\begin{array}{l}\text { Avg Fracture Energy } \\
\left(\mathrm{J} / \mathrm{m}^{2}\right)\end{array}$ & $\begin{array}{l}\text { Percentage decrease } \\
\text { in Fracture Energy }\end{array}$ \\
\hline 20 & 692.5 & - \\
\hline 100 & 585 & 15.52 \\
\hline 300 & 426 & 38.48 \\
\hline 500 & 194 & 71.9 \\
\hline 700 & 85 & 87.7 \\
\hline 900 & 61.25 & 91.1 \\
\hline \multicolumn{3}{|c|}{ Basalt fiber concrete concrete prisms } \\
\hline $\begin{array}{l}\text { Temperature } \\
\left({ }^{0} \mathrm{C}\right)\end{array}$ & $\begin{array}{c}\text { Avg Fracture Energy } \\
\left(\mathrm{J} / \mathrm{m}^{2}\right)\end{array}$ & $\begin{array}{l}\text { Percentage decrease } \\
\text { in Fracture Energy }\end{array}$ \\
\hline 20 & 1067.5 & - \\
\hline 100 & 966.25 & 9.48 \\
\hline 300 & 850 & 20.37 \\
\hline 500 & 612 & 42.66 \\
\hline 700 & 408.25 & 61.75 \\
\hline 900 & 340.5 & 68.10 \\
\hline
\end{tabular}

Fracture Toughness OF Plain and Basalt Fiber CONCRETE PRISMs

\begin{tabular}{|c|c|c|}
\hline \multicolumn{3}{|c|}{ Plain concrete prisms } \\
\hline $\begin{array}{c}\text { Temperature } \\
\left({ }^{0} \mathrm{C}\right)\end{array}$ & $\begin{array}{c}\text { Fracture } \\
\text { Toughness }\left(\mathrm{K}_{\text {ic }}\right)\end{array}$ & $\begin{array}{c}\text { Percentage } \\
\text { decrease in fracture } \\
\text { toughness }\end{array}$ \\
\hline 20 & 169.86 & - \\
\hline 100 & 153.98 & 9.34 \\
\hline 300 & 131.39 & 22.64 \\
\hline 500 & 78.08 & 54.03 \\
\hline 700 & 44.75 & 73.6 \\
\hline 900 & 34.97 & 79.4 \\
\hline \multicolumn{3}{|c|}{ Basalt fiber concrete concrete prisms } \\
\hline $\begin{array}{c}\text { Temperature } \\
\left({ }^{0} \mathrm{C}\right)\end{array}$ & $\begin{array}{c}\text { Fracture } \\
\text { Toughness }\left(\mathrm{K}_{\text {ic }}\right)\end{array}$ & $\begin{array}{c}\text { Percentage } \\
\text { decrease in fracture } \\
\text { toughness }\end{array}$ \\
\hline 20 & 215.49 & - \\
\hline 100 & 199.98 & 15.5 \\
\hline 300 & 182.07 & 46.93 \\
\hline 500 & 151.89 & \\
\hline 700 & 114.36 & \\
\hline
\end{tabular}

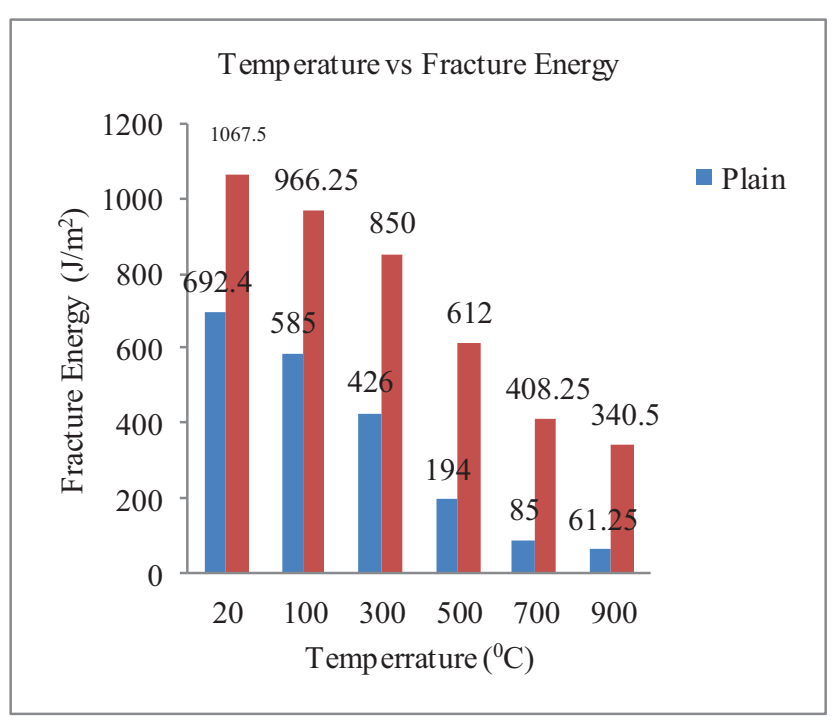

Figure 5. Fracture Energy of Plain and basalt Fiber concrete prisms at different temperatures.

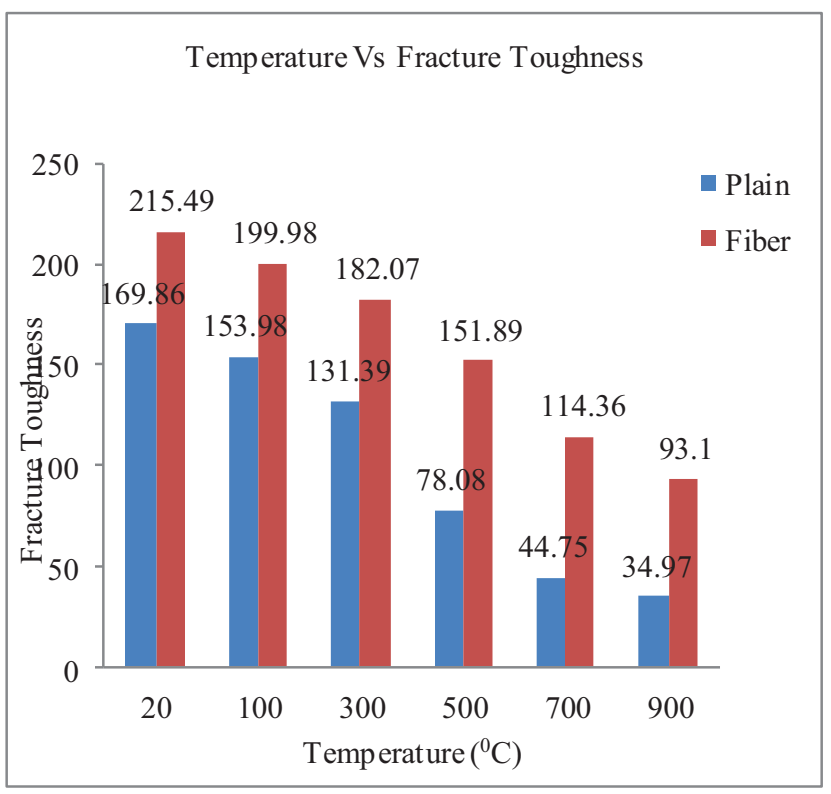

Figure 6. Fracture Toughness of Plain and basalt Fiber concrete prisms at different temperatures. 


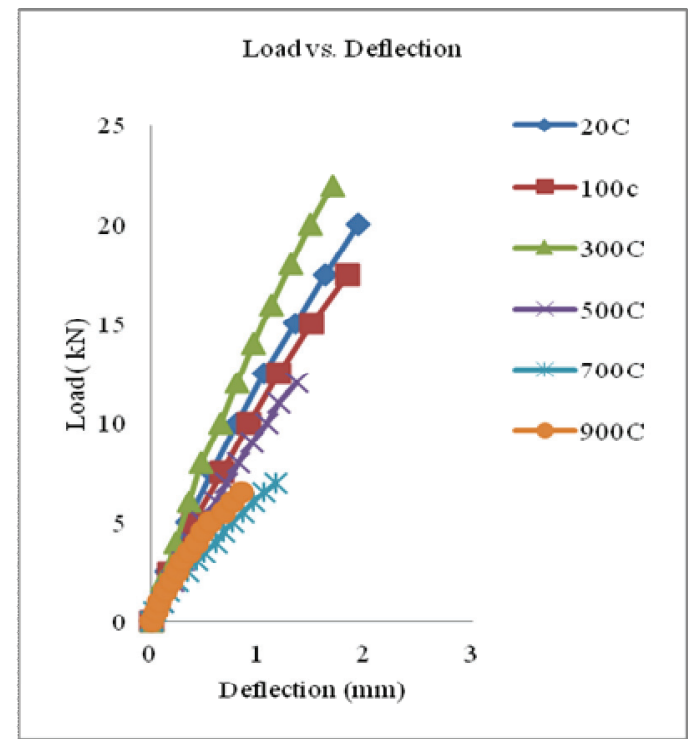

Figure 7. Load-Deflection of Plain concrete prisms at different temperatures

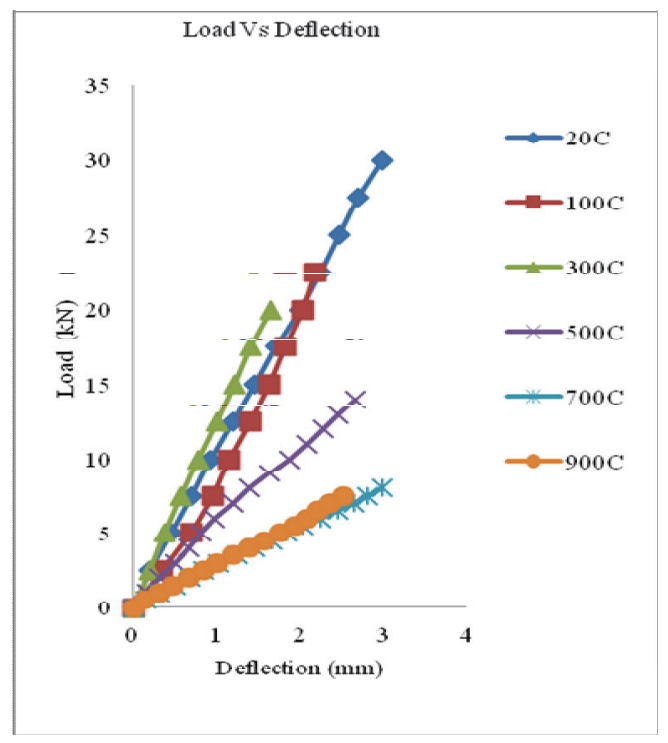

Figure 8. Load-Deflection of Fiber concrete prisms at different temperatures

\section{Conclusions}

The sustaining temperature and melting temperature of Basalt fiber is $680^{\circ} \mathrm{C}$ and $1450^{\circ} \mathrm{C}$ respectively. Since the sustaining temperature of Basalt fiber is $680^{\circ} \mathrm{C}$, the decrease in residual compressive strength, flexural strength, split tensile strength and modulus of elasticity is less than $15 \%$ up to $500^{\circ} \mathrm{C}$. The percentage decrease in average Fracture energy (single point loading) and fracture toughness at $500^{\circ} \mathrm{C}$ for basalt fiber concrete prisms was $42.66 \%$ and $29.51 \%$ respectively. Even at $900^{\circ} \mathrm{C}$, the average percentage decrease in fracture energy and fracture toughness was $68.1 \%$ and $56.79 \%$ respectively. Due to the strong flexural resistance of basalt fiber, there was less decrease in the strength parameters and fracture parameters. Hence, use of Basalt fiber in high strength concrete is recommended.

\section{REFERENCES}

[1] Duaa Fadil, Nildem Taysi, Abdullah Ahmed "The investigation of basalt and glass fibers on the Behavior of reinforced concrete beams". International Journal of Advances in Mechanical and Civil Engineering, Volume-5, Issue-3, Jun.-2018.

[2] T. Parthiban, G. Pavithran, C. Pradeep, BA. Praveen Kumar, Mrs. Devi S. "Durability of concrete by adding basalt fiber". International Research Journal of Engineering and Technology (IRJET), Volume: 04 Issue: 09, September -2017.

[3] M Aathithya Raja, G Saravanan, V.S Satheesh. "Flexural Behaviour of Basalt Chopped Strands Fibre Reinforced Concrete Beams". International Journal of Engineering Science and Computing, Volume 7 Issue No.3, March 2017.

[4] N. Gopi, P. Baskar, B. Dharani and P. Abinaya "Experimental investigation of concrete with basalt fibre". International Journal of Emerging Technology in Computer Science \& Electronics (IJETCSE) Volume 21 Issue 1 - April 2016.

[5] Mohammed Ishtiyaque and M.G. Shaikh "Fracture behavior of concrete reinforced with basalt fiber" Journal for advanced research in applied sciences, volume-4, Issue 7, 2017

[6] Kirankumar, chetan V R "Experimental investigation on basalt fiber reinforced concrete". International journal of scientific Development and Research. Volume 2, Issue 6, June 2017.

[7] M.P.Suresh kumar, S. Ramesh, P.eshwaran, P.Pruthiraj "Basalt fiber application in concrete". International Journal of advanced science and research. Volume 1, Issue 1, June 2016.

[8] Suchita Hirde and Sagar Shelar"Effect of Basalt Fiber on Strength of Cement Concrete". International Journal of Current Engineering and Technology, 2017.

[9] Zhenshan Wang, Kai Zhao, Zhe Li, Hui Ma "Experimental Study on Durability and Mechanical Properties of Basalt Fiber Reinforced Concrete under Sodium Sulfate Erosion". volume 62, 2017.

[10] C.V.Neilson, and N.Bicanic" Residual fracture energy of high performance and normal concrete subject to high temperatures". Materials and structures volume 36, October 2006. 